Binghamton University

The Open Repository @ Binghamton (The ORB)

The Society for Ancient Greek Philosophy Newsletter

$12-28-2010$

\title{
A Religious Revolution? How Socrates' Theology Undermined the Practice of Sacrifice
}

Anna Lannstrom

Stonehill College, alannstrom@stonehill.edu

Follow this and additional works at: https://orb.binghamton.edu/sagp

Part of the Ancient History, Greek and Roman through Late Antiquity Commons, Ancient Philosophy Commons, and the History of Philosophy Commons

\section{Recommended Citation}

Lannstrom, Anna, "A Religious Revolution? How Socrates' Theology Undermined the Practice of Sacrifice" (2010). The Society for Ancient Greek Philosophy Newsletter. 460.

https://orb.binghamton.edu/sagp/460

This Article is brought to you for free and open access by The Open Repository @ Binghamton (The ORB). It has been accepted for inclusion in The Society for Ancient Greek Philosophy Newsletter by an authorized administrator of The Open Repository @ Binghamton (The ORB). For more information, please contact ORB@binghamton.edu. 


\title{
A religious revolution? How Socrates' theology undermined the practice of sacrifice ${ }^{1}$
}

\author{
Anna Lännström, Stonehill College \\ Presented to the Society for Ancient Greek Philosophy at its 2010 meeting with the \\ Eastern Division of the American Philosophical Association
}

It is generally accepted that Socrates' religious views were at least somewhat unconventional and that they may have seemed threatening to other Athenians. ${ }^{2}$ Pinpointing in what ways Socrates' views were unconventional and in what ways they threatened conventional Athenian religion, however, has proven difficult. This is partly because Socrates' religious views have been hotly debated over the centuries. Furthermore, through the work of Mark McPherran and others, philosophers have become increasingly aware that Athenian religion is not simply reducible to belief in the erratic Homeric twelve. We are now much more likely to recognize the complexity of Athenian religion, as well as its tendencies towards orthopraxy rather than orthodoxy. Taking Athenian religion's focus on orthopraxy seriously, some scholars have argued that Socrates' views were threatening at least in part due to their consequences for religious practice. ${ }^{3}$ This paper examines Mark McPherran's and Gregory Vlastos' arguments that Socrates' theology threatened Athenian sacrificial practices because it rejected the so-called do ut des principle (I give that you may give, aka the principle of reciprocity). ${ }^{4}$

The first part of this paper summarizes Vlastos' and McPherran's arguments. The second provides a brief overview of sacrifice in Athens and then argues that Vlastos' and McPherran's arguments are flawed because they assume that the Athenians understood sacrifice in terms of the do ut des principle. ${ }^{5}$ Drawing upon scholarship in anthropology and religious studies, I argue that we need to revise that understanding of sacrifice and that, once we do, McPherran's and Vlastos' arguments no longer show that Socrates would have been a significant threat to the practice of sacrifice. The final part argues that McPherran's Socrates does undermine sacrifice, but not for the reasons that McPherran suggests. Rather, he undermines sacrifice by making external actions irrelevant to piety.

\section{Part 1: Background and summary of McPherran and Vlastos}

Sacrifices were an integral part of the life and religious practices of Athens, and state sacrifices were organized in an extensive calendar. ${ }^{6}$ Because sacrifices were one of

${ }^{\top}$ The full version of this paper is forthcoming in Ancient Philosophy.

${ }^{2}$ After all, he was found guilty of not acknowledging [nomizein] the gods of the city and of introducing new deities.

${ }^{3}$ The term nomizein can mean either "believe in" or "acknowledge," indicating a charge of heterodoxy or heteropraxy respectively. Cf. Burnet (note to Apology 24c1, 184), Garland (1992) and McPherran's response to Garland (2002, 164).

${ }^{4}$ Vlastos (1991); McPherran (2002). None of them suggest that this was the only way in which Socrates' religious views deviated from the norm or that concerns about the sacrifices really did motivate the trial. I'll focus largely on McPherran's more extended argument.

${ }^{5}$ Gocer also notes that do ut des is not the right way of understanding the relationship between gods and humans in Greece $(2000,122)$. Her discussion is very brief, however, and so she does not provide an extended argument for this view.

${ }^{6}$ Sources on sacrifice in ancient Greece abound; see especially Bowie (1995), Bremmer (2007), Jameson (1988), Mikalson (1983 and 2010), Price (1999), and Zaidman and Pantel (1989). 
the primary ways in which the gods were honored, changes to them were a serious matter, often done only with the approval by the Delphic oracle. ${ }^{7}$ A few years before Socrates' trial, Nicomachus was asked to revise Solon's sacrificial calendar for Athens, and was then brought to trial on impiety charges. The prosecutor argued that one must make no changes whatsoever to the calendar. ${ }^{8}$ We should not infer that the sacrifices were never changed. After all, Nicomachus was asked by the city to make the revisions. Changes were made fairly regularly, for financial or for other reasons. Still, advocating changes to the sacrifices could be a sensitive and risky matter. ${ }^{9}$

Now, neither McPherran nor Vlastos believe that Socrates set out to reform the sacrifices in the direct way that Nicomachus did. The threat he posed was indirect; his theology undermined sacrifices by suggesting that they would not sway the gods. Vlastos argues that Socrates would abandon sacrifice completely, replacing it with moral philosophy $(1991,175)$.

McPherran greatly expands and revises Vlastos' argument. Other than his greater caution and more moderate tone, the main difference is that, unlike Vlastos, McPherran believes that Socrates retained a role for prayer and sacrifice. He argues, following Yunis (1988), that Athenian religion was organized around three core beliefs: The gods exist; they take notice of human affairs; and they respond to our sacrifices and prayers (2002, 170). McPherran describes the Greek religious practice of sacrifice as follows:

[The practice] often centered on prayers to a divinity, and these almost always involved a request for a particular (not general) and materially manifested good. ... However, like any superior, it was thought useful to put such supernatural assistants in one's debt first in order to "enlist" them in one's cause (or to reward them subsequent to their services). Thus, it was typical to accompany a prayer of request with an offering of some sort designed to establish a claim on the "helper" .. . As Euthyphro confesses to Socrates (Euth. 14c-15a), this do ut des "I give so that you will give" - conception of reciprocity between gods and humans is rather like an art of commerce (emporikê; 14e8). $(2002,165)$

As Socrates forced Euthyphro to admit, then, traditional Greek sacrifice was a transaction in which people paid for the gods' help with their sacrifices. McPherran argues that this do ut des conception of sacrifice is supported by the traditional view of justice as reciprocation (lex talionis) according to which you should repay a gift for a gift and an evil for an evil (ibid.). The point of the sacrifices was to put the gods in your debt, making them feel that they have to help you next time. This may mean helping you with your crops or against the plague, but it may also include helping you take revenge on your enemies. Finally, McPherran argues that passages from texts like the Iliad, Medea, the Republic, and the Laws suggest that the Athenians believed that the gods could be persuaded to violate lex talionis (ibid., 170). ${ }^{10}$

In McPherran's view, Socrates accepted the first two core beliefs of Athenian religion: the gods exist and they care about the affairs of human beings. However, his theology required him to reject (or at least radically modify) the belief that the gods

\footnotetext{
7 See Isocrates Areopagiticus 7.29-30; the pseudo-Aristotelian Rhetoric to Alexander (1423a-b). Cf. Mikalson $(2010,171)$ and Price $(1985,144)$.

${ }^{8}$ Lysias 30, 18.

${ }^{9}$ Cf. Mikalson (ibid.).

${ }^{10}$ He notes that other texts suggest that the gods could not be persuaded in this way.
} 
respond to sacrifices. Since the gods are just, they simply cannot be persuaded to assist with an unjust action, no matter what sacrifices we offer them. On this point, then, McPherran argues, Socrates departed from the traditional Greek view; he rejected do ut des sacrifice.

Vlastos concluded that Socrates rejected the Athenian tradition of sacrifice altogether. McPherran disagrees, arguing that Vlastos is wrong to assume that do ut des was the only Greek views of sacrifice (ibid, 171). While do ut des was the dominant view, there was also a second, non-mercantile view, according to which gods are influenced not by the size of the sacrifice but by the character and virtue of the petitioner (ibid.). And this view would of course be much more conducive to a Socratic interpretation.

Thus, for McPherran, Socrates' revolution was not a threat to all cult as Vlastos suggests. He was a threat to those who thought that the point of cult was to bribe the gods with big material sacrifices. Still, like Vlastos, McPherran understands sacrifice as a do ut des transaction. He explicitly equates the gods' responding to sacrifice with a do ut des cult: "[The gods] will respond to some of our actions ... especially our prayers and sacrificial offerings (that is, they are gods with a do ut des cult)" (2002, 168, emphasis added). ${ }^{11}$ And because he understands sacrifice in that way, McPherran agrees with Vlastos that the implications of Socrates' critique of sacrifice cut "straight at the root of some of the popular traditional motivations underlying many cult practices" (ibid., 174) and that Socrates "revolutionized the traditional notions of piety and 'honoring" (ibid., 172).

Part 2: Critique of the do ut des view of sacrifice

McPherran and Vlastos' position comes down to two claims: the Athenian institution of sacrifice was largely a do ut des practice, and Socrates rejected all (Vlastos) or the dominant part (McPherran) of it. I agree that Socrates would have found this sort of transaction between man and god completely unacceptable. But I will argue that do ut des is not an accurate understanding of the function of sacrifice in general and in Athens in particular and that, consequently, Socrates' criticism of do ut des sacrifice was not such a large threat.

In the Euthyphro, Socrates and Euthyphro are discussing something that seems very much like the do ut des conception of sacrifice. But notice that it is Socrates who calls it "how to give to [dôreisthai] and beg from" the gods (14c) and then turns it into "a sort of trading skills [emporikê] between gods and men" (14e). Euthyphro himself presents piety in terms of charis, a rich concept which refers to the reciprocal relationship between humans and gods. ${ }^{12}$ Socrates omits charis from consideration completely when he revises Euthyphro's definition, turning it into a trade. ${ }^{13}$ Euthyphro does not protest, although his response -- "trading yes, if you prefer to call it that" (14c) -- perhaps suggests a discomfort with the revision. A more savvy interlocutor might have been able to provide a more respectable reason for why the Athenians make gifts to the gods.

"Cf. also one of his later articles: "Such [sacrificial] practices, however, typically assumed that justice consists in do ut des reciprocation" (2006, 85).

${ }^{12}$ See $14 \mathrm{~b}$ where Euthyphro uses cognates of charis twice. For good discussions of charis, see Mikalson (2010, 24-5), Parker (1998), and Yunis (1988, 101-11).

${ }^{13}$ Cf. Yunis 1988, 101-2. 
Theophrastus for instance argued that people sacrifice to show gods honor, to give them thanks, and to express their need of benefits (On piety, frag. 12). ${ }^{14}$ Like Socrates, the do ut des formula takes these three reasons and collapses them into one: We thank and honor the gods as payment for the benefits we need from them. But that is not what Theophrastus said, and it is not what Euthyphro said either.

There are plenty of votive inscriptions and passages in our texts that suggest the do ut des view. Based on them, it is easy to conclude that sacrifice must be a mere trade. But was do ut des as dominant as McPherran suggests? McPherran does not offer an argument for this claim but rather refers to other scholars and especially to Yunis (1988, chapter $3) .{ }^{15}$ Yunis argues that much religious activity in fact amounted to nothing more than $d o$ ut des transactions and that the do ut des interaction is especially visible in sacrifices, prayers and votive offerings $(1988,54)$. In the footnote, he cites van Straten's discussion of votives (1981). However, van Straten himself rejects do ut des and argues that we should view the votive offering as a means "to bring about and sustain a relationship between man and god" (ibid., 80). Furthermore, despite apparently embracing do ut des in chapter 3, Yunis actually agrees with van Straten. Later in the book, he argues that inscriptions on votive offerings "elevate the relationship of dedicator and god beyond a mere commercial contract to a preferential reciprocity based on mutual esteem" (1988, 103). It is a matter of charis, and so, Yunis concludes, the transaction is "outside the realm of mere business" (1988, 102).

So what exactly is the difference between do ut des and the view that Yunis and van Straten are attributing to the Greeks? On Yunis and van Straten's view, people and gods are not trading partners but have a relationship of mutual esteem, and they exchange gifts in order to maintain that relationship. They do not esteem each other because of the gifts, but the gifts are still important, just as they can be in human relationships. If we never sacrificed to the gods, our neglect would damage our relationship with them and if our relationship were damaged, the gods might not help us prosper. But that does not mean that sacrifices pay for the prosperity as they do on the do ut des view.

Yunis and van Straten are not denying that the relationship between humans and the gods was reciprocal or that many people were engaging in do ut des transactions. It was and they did. Their point, rather, is that sacrifice is not reducible to do ut des. Here, they and I are following the vast majority of scholars in religious studies and related fields, who argue that sacrifice is more complex than the do ut des conception allows and that, as just noted, it is more like gift giving than a trade. ${ }^{16}$

\footnotetext{
${ }^{14}$ Porphyry On Abstinence 2.24; Pötscher 42-4.

${ }^{15}$ See notes 26, 44, 47, and 85 (2002) where he refers mainly to Yunis (23-58) but also to Dodds (1973, 144-155); Dover (1974, 246-9); Vlastos (1991, 176-177); and Lloyd Jones (1971, 156-64). Lloyd Jones does not offer any support of do ut des in those pages (or anywhere else in the book, as far as I can tell). Vlastos and Dover both assume but do not argue for the do ut des view. Dodds presents some evidence, but it will become clear as I proceed that this evidence can be explained equally well if we view sacrifice as a gift.

${ }^{16}$ My discussion here will follow van Baal (1976) closely. See also the following: Bremmer: "All this 'traffic' between god and man should not be seen in a framework of contract (do ut des), but in one of goodwill and friendship" (1998, 133); G. S. Kirk: "Scholars are usually content to reduce the whole business of ... gifts to the over-simple and much-distorted legal principle of do ut des, a tag which serious discussions of divine ritual could well do without" (1980, 74-5); Mikalson: "[Sacrifice involves a] more subtle and complex [relationship] than the formula do ut des ... often used to describe it implies" (2010, 24); Parker: "A very commercial interpretation of kharis is not an error pure and simple; it might, none the
} 
Gift giving and trade are different in important ways. Unlike trade which is a limited one-time transaction, a gift also strengthens social relations between giver and receiver. And indeed, gifts were an important way of establishing relations with people outside the immediate family in Athens (and elsewhere). ${ }^{17}$ As van Baal points out, gifts send a strong message that a trade does not: "[I] regard you as a partner, appreciate you as a friend, as one who belongs to us" $(1976,167)$.

Furthermore, if sacrifice were a trade, the gods' willingness to participate would seem utterly mysterious because they get so little out of it. As van Baal explains, the situation appears quite different if we view the sacrifice as a gift. Whereas a trade presupposes that the goods are of equal value, gifts are often tied to social position, so that the person in the lower position gives a smaller and the higher person a larger gift. Since the sacrificer is much inferior to the gods, it makes perfect sense for them to give him much bigger gifts than he could ever hope to give to them.

Now, van Baal continues, when we make an offering to a god, we ask for a favor as we hand over the gift. This has suggested to the proponents of a do ut des approach that the gift is intended to purchase the favor, as if we were handing cash to the cop together with our license and registration. ${ }^{18}$ But van Baal argues that this is a misunderstanding and that given the enormous difference in status and power between human and god, the request is an appropriate part of the gift $(1976,170)$. By making a request, we are highlighting our dependence upon the god and our recognition that, as Socrates argues in the Euthyphro, the gods really need nothing from us.

Finally, as van Baal cautions, saying that sacrifice is better understood as gift giving does not mean that every sacrifice was performed as a gift. Exactly because gift giving is such a powerful way of establishing contacts and improving relations, gifts can be misused and reduced to more or less overt bribes. While sacrifice at its best can be a gift which deepens and improves our relationship with the gods, at its worst it can become a calculating attempt to bribe the gods.

There are many possible motivations for making offerings to the gods, and some of that variety is displayed on the inscriptions on votive offerings from Socrates' era. ${ }^{19}$ Some suggest what sounds like a straightforward do ut des. Others express gratitude. There are offerings which honor a god. Some of the votives were in memory of the person presenting the offering. Another yet was inscribed to a god "as proof of [his] miraculous power, for all to see" (ibid., 77).

It seems reasonable to assume that the motivations of people for sacrificing were just as varied as the written dedications on the votive offerings and just as varied as people's motivation for attending church are today. ${ }^{20}$ Furthermore, there seems to be no reason to think that each individual would have only one motive for sacrificing. Our one autobiographical account, Xenophon's Anabasis, shows that he sacrificed for a variety of

less be a distortion or drastic over-simplification; and for several reasons those who have argued that it is are surely in the right" (1998, 118); Price: "Moderns of an anti-ritualistic bent criticize [the relationship between man and god in a sacrifice] as merely do ut des .... But such criticism misses the point" $(1999,38)$. Cf. also Jameson $(1988,975)$ and Lambert (1993, 310).

${ }^{17}$ Cf. Kirk (1980, 75).

${ }^{18} \mathrm{Cf}$. McPherran: "It was typical to accompany a prayer of request with an offering of some sort designed to establish a claim on the "helper"' (ibid. 165).

${ }^{19}$ See van Straten (1981) for a collection of Greek inscriptions from votive offerings.

${ }^{20}$ Cf. Bremmer (2007, 144), Kirk (1980), and Zaidman and Pantel (1989, 29). 
reasons. Most often, at least when returning from his military adventures, he seems to have sacrificed to see if the omen were favorable for the action he was considering. ${ }^{21}$ But we also see him sacrifice to thank the gods, to ensure a good journey, and to placate a neglected god. ${ }^{22}$ Finally, the same individual may well have more than one motive on a single occasion. In a single sacrifice, he may aim at thanking the gods, putting on a splendid display that would impress guests from out of town, and at eating meat.

There are occasional hints in McPherran that he recognizes that the do ut des account may be too facile and that there are other motives for performing sacrifices. ${ }^{23}$ However, his argument that Socrates indeed was a threat and a revolutionary hinges upon the assumption that the do ut des view of sacrifice was so dominant that a critique of it would have been regarded as a serious threat and perhaps even as a wholesale rejection of the whole institution of sacrifice. ${ }^{24}$

Let us assume that Socrates were able to persuade everybody in Athens that the gods are good, that they cannot be bribed, and that they all agree. How would that affect sacrifice in general? McPherran argues that Socrates' views threaten sacrifices in three main ways. First, McPherran argues that "to many Athenians the assistance of a [hero like] Heracles would have meant, above all, help against the unseen, non-human (and so less easily dealt with) forces bearing down on one, and for most of them this meant help against oppressive other deities" (ibid., 174). However, somebody who has accepted Socrates' views would regard such help as impossible. Since the gods all agree, one of them will not help you against another (ibid., 175).

I do not find this argument compelling. McPherran offers no evidence that Athenians asked for divine help mainly to deal with oppressive deities. Such evidence is needed, especially since no less an authority than Mikalson argues that the Athenians generally avoided blaming any bad things on the gods, instead blaming bad fortune or some daimon $(1983,50,60)$. If he is right, Socrates' view on this point should have struck them as quite orthodox. Furthermore, even if McPherran were right and Mikalson wrong, Socrates revisions to Athenian prayer practices on this point seem minor: Instead of thinking of the cause of the bad things as another deity, which they now would know it could not be, the Athenians could simply regard the cause as bad luck and continue to ask for the gods' help against it.

Second, McPherran argues, Socrates' reforms meant that we cannot count on the gods for help with particular bad stuff in life because that bad stuff may well be designed to help us improve (ibid., 174-5). This would be a radical change, McPherran continues, since most of the Athenians prayers were requesting help with specific practical problems (ibid., 165). In my view, though, the possibility that some of these obstacles may have been put in their way to make them better people would not prevent people from asking

\footnotetext{
${ }^{21}$ See for instance Anabasis 5.5, 5.6, 6.1, 6.2, 6.4, 6.5, 7.6, and 7.8.

${ }^{22}$ See for instance the following: for a good journey $(3.1)$, to thank a god $(3.1,3.3)$, to placate a god $(7.8)$.

${ }^{23}$ As already noted, McPherran recognizes that some people had nonmercantile motivations. Furthermore, at one point, he writes that "sacrificial activity was often not so much aimed at obtaining specific goods or evils as at maintaining an ordered relationship with the gods and ensuring their general good will, a will that (it was generally agreed) could not be reliably influenced by such activity" $(2002,171)$. But his argument does not incorporate this insight.

${ }^{24}$ Socrates was offering "a virtual repudiation of cult, given that the "everyday particularized, materially oriented and self-interested (even retaliatory) motives" which he so sharply criticized were often the primary motives in play $(2002,175)$.
} 
for help in dealing with them. We do not know whether the obstacle is supposed to be virtue inducing. If it is, God will not remove it for us, but perhaps He will still help us deal with it. And if the obstacle is not virtue inducing, perhaps He is just waiting for us to ask for help with it? In either case, it does not hurt to ask.

Now, McPherran does not discuss it in this context but, as he of course knows, Socrates also objected to the content of people's prayers for a different reason: People often asked for wealth, political power, and honors. ${ }^{25}$ As Socratics, the content of their prayers would have to be radically different; they would ask for whatever would improve the soul and promote virtue. However, this change does not constitute a criticism of prayer and sacrifice per se. Rather, it is a particular instance of Socrates' overarching criticism of Athenian misguided values. ${ }^{26}$ Thus, this criticism may threaten the Athenian way of life, but it does not threaten the institution of prayer and sacrifice.

Finally, McPherran argues that the view that the gods are just would make people significantly less likely to ask for divine help with their more shady dealings (ibid., 170). Thus, Socrates' reforms would severely restrict the range of prayer and sacrifice. I am not persuaded, however, that they would be less likely to ask for help. As McPherran himself recognizes, the Greeks themselves seem divided on whether the gods would actually help them to do something bad. This means that at least those who already agreed with Socrates on this point presumably were already restricting prayer and sacrifice in the way Socrates suggests that they should. Furthermore, people rarely describe what they themselves do as unjust and bad. Instead, we usually convince ourselves that what we are about to do is really good (or at least not bad) and that the gods therefore will be on our side. This way of thinking seems to be at play in some of the very passages that McPherran cites $(2002,170)$ as examples of people asking for help with unjust enterprises: Medea aimed to exact "just payment with God's help" (Medea 803; emphasis added). The opening prayer for the Boule included a curse on those who plotted evil against Athens.

If the Athenians accepted Socrates' reasons for rejecting do ut des sacrifice, they would have to abandon do ut des sacrifice but not the sacrifices performed for many of the other reasons mentioned above. They could continue sacrificing in order to maintain a good relationship with the gods, to thank them, to praise them, and to divine the future. Given the multiple and complex motivation for sacrifice, Socrates' challenge to do ut des does not seem to be that significant of a threat.

Part 3: Why McPherran's Socrates still is a threat

Despite all this, I agree that if McPherran's understanding of Socrates' views is accurate, Socrates was a threat to traditional sacrifice. To see why this is so, consider how McPherran outlines the role that his Socrates would allot to sacrifice: We should indeed honor the gods and "there is no reason why such actions cannot include thanks-offering prayers and material sacrifices" $(2002,173)$. Such prayers are virtuous because they are attempts to offer good in exchange for good (ibid.). But while prayer and sacrifice are "compatible" with piety, especially if they are performed with a "correct god-honoring

\footnotetext{
${ }^{25}$ McPherran notes that the gods would sometimes wait for us to make a request before giving us something and that they would only grant requests that would be "virtue-aiding" (ibid, 173-4), but he does not in this context further discuss the Socratic critique of prayers for material goods.

${ }^{26}$ Cf. Apology 29e.
} 
intention," they are not "essentially connected" to it (ibid., 172-3). The best way of honoring the god is through "philosophical self-examination" (ibid. 173). McPherran also notes that Socrates would probably have recognized that sacrifice has an important social role (ibid.). It was part of the written and unwritten nomoi of Athens, and it fosters and maintains the community. In this role, sacrifice remains profoundly important, but it has nothing to do with the gods; it is all about the relationship between the citizens and between the citizens and their laws.

This view poses a threat to a more traditional view because while McPherran's Socrates does not object to sacrifices, he all but obliterates their significance in our relationship to the gods. The gods do not mind sacrifices, but they also do not particularly want them. They appreciate the sentiment of gratitude and honor expressed in the sacrifice, but they care only about that inner intention and sentiment, not its outward manifestation. They would rather be honored through philosophy. As McPherran himself puts it, Socrates and Plato regarded a sacrifice or a prayer as an "epiphenomenon of [the petitioner's] inner piety" (ibid., 176). Performing sacrifices is not "sufficient evidence" that you are pious (ibid.), and refraining does not show that you are impious. This means that sacrifices are no longer a vital part of how we maintain the relationship with our gods. They are part of Athenian nomoi but for no good reason. They are, so to speak, mere custom, and they may become a problem if they take up time that would be better spent philosophizing. Furthermore, some especially adventurous follower of Socrates might suggest that the sacrifices impede our relationship with the gods since our continuing the sacrifices suggests that we have failed to understand what is important.

The demotion of sacrifices to the status of epiphenomena seems unavoidable once one regards them as external behavior and contrasts them with the all-important state of the soul. Thus McPherran's Socrates opens the door to the gradual abandonment of sacrifice altogether, to be replaced by philosophy and occasional prayers for what we need for the improvement of our souls. This abandonment would not happen immediately because if Socrates were in charge, his respect for the nomoi would make him unwilling to make such a radical change. But given how McPherran's Socrates regards the sacrifices, he seems to be in the uncomfortable position of encouraging empty ritual. As McPherran suggests, Socrates might defend the sacrifices by regarding them not as gifts to the god but simply as rituals in which a community comes together and is unified and he might argue that this makes it important to continue them. He might also argue that sacrifices should continue since they are making us better by "habituating us to return good for good" $(2002,173)$. And so, his Athenians might continue these sacrifices indefinitely. But they might also decide that performing sacrifices to gods who do not want sacrifices is not the best way of keeping the community together and of making people better, and so they might replace them with a different means to attain the same goals.

That this end point would be threatening to the institution of sacrifice should be obvious. Moreover, the new understanding of piety is a threat from the very beginning. First and foremost, the view that only the intention behind the sacrifice matters, not the sacrifice itself, would be deeply objectionable to anybody who regarded sacrifices as more than epiphenomena. If the actual sacrifices are important and required ways in which we maintain our relationships with the gods and if we neglect them at our peril, 
then Socrates is dangerously wrong. And this view of sacrifices, as I have previously argued, was common in Athens.

Regardless of how much of this his fellow citizens saw and understood, Socrates' view that only the intentions and inner states matter presented a real threat to the institution of sacrifice. Whatever Socrates' intentions may have been, his views encouraged people to neglect the sacrifices, thereby failing to honor the gods and damaging the city's relationship with the gods. They invited his followers to make a radical break with tradition, abandoning the sacrifices that the Athenians had practiced since time immemorial. Indeed, his new way of honoring the gods through philosophy instead of sacrifice was different enough that it looked much like a refusal to honor them at all.

The views about sacrifice and piety that McPherran attributes to Socrates were radical and different. Regardless of what Socrates himself intended, they could easily be extended into a call for a virtual abolishment of sacrifices. But were they in fact Socrates' views? It seems clear that Socrates would have rejected any attempts to bribe the gods and that he would have argued that sacrifices without a good intention would do no good. It seems equally clear that he was sure that prayers for excessive wealth, political power, and honors were fundamentally misguided. But that is an objection to the content of people's prayer, not to the practice as such. Did he believe that there was nothing to sacrifices except a do ut des transaction? The passages from the Euthyphro discussed earlier in this paper do suggest that he saw them as at worst attempts to buy the gods' favor and at best as optional manifestations of inner piety, important due to respect for the nomoi. However, I believe that his view might have been more tentative than that. For Socrates to conclude that the gods are interested only in our state of mind and that the sacrifices are not intrinsically important to them amounts to a claim to know the mind of the gods. ${ }^{27}$ Given Socrates' constant expressions of ignorance about such matters, I find it difficult to believe that he would make such claims, especially since the oracle at Delphi continually reaffirmed the importance of the sacrifices. The oracle's support for sacrifices should have induced Socrates to suspect that they might have an intrinsic value even if he was unable to see it himself. My guess then is that the historical Socrates would have shared the sentiment his counterpart expresses in the Republic (427b): Questions about establishing and abolishing sacrifices should be left in the hands of Apollo because he knows the value of such sacrifices better than we do.

\section{Bibliography}

Bowie, A. M. 1995. "Greek sacrifice: Forms and functions.” The Greek world. Ed. A.M. Powell, London: Routledge, 463-82.

Bremmer, J. N. 2007. "Greek normative animal sacrifice.” Companion to Greek Religion. Ed. D. A. Ogden. Oxford: Blackwell, 132-44.

---. 1998. "The reciprocity of giving and thanksgiving in Greek worship." Reciprocity in ancient Greece. Eds. C. Gill, N. Postlethwaite and R. Seaford. Oxford: Clarendon Press, 127-137.

Burnet, J. 1924. Euthyphro, Apology of Socrates, Crito. Clarendon Press: Oxford UP.

Dodds, E. R. 1973. "The religion of the ordinary man in classical Greece." Rpt. in The ancient concept of progress and other essays on Greek literature and belief. Oxford: Clarendon Press. 140-155.

Dover, K. 1974. Greek popular morality in the time of Plato and Aristotle. Berkeley and Los Angeles: Blackwell and University of California Press.

${ }^{27}$ Cf. Gocer $(2000,122)$. 
Garland, Robert. 1992. Introducing New Gods: The Politics of Athenian Religion. Ithaca, Cornell UP.

Gocer, Asli. 2000. "A new assessment of Socratic philosophy of religion." Reason and religion in Socratic philosophy. Eds. N. Smith and P. Woodruff. Oxford: Oxford UP, 2000. 115-129.

Jameson, M. H. 1988. "Sacrifice and ritual: Greece." Civilization of the ancient Mediterranean. Greece and Rome 2. New York: Price Stern Sloan Publishing, 959-79.

Kirk, G. S. 1980. "Some methodological pitfalls in the study of ancient Greek sacrifice (in particular)." Le sacrifice dans l'antiquité. Vandoeuvres, Geneve: Fondation Hardt.

Lambert, M. 1993. "Ancient Greek and Zulu sacrificial ritual. "Numen 40: 293-318.

Lloyd-Jones, H. 1971. The justice of Zeus. Berkeley, California: University of California Press.

McPherran, Mark L. 2006. "The gods and piety of Plato's Republic." The Blackwell guide to Plato's Republic. Ed. G. Santas. Malden MA: Blackwell Publ.

---. 2002. "Does piety pay? Socrates and Plato on prayer and sacrifice." In The trial and execution of Socrates: Sources and controversies. Ed. T. Brickhouse and N. Smith. New York: Oxford UP: 162-190. Previously in Reason and religion in Socratic philosophy. Eds. N. Smith and P. Woodruff. Oxford: Oxford UP, 2000: 89-114.

Mikalson, Jon. 2010. Ancient Greek religion. Malden, MA: Blackwell.

---. 1983. Athenian popular religion. Chapel Hill: University of North Carolina.

Parker, Robert. 1998. "Pleasing thighs: reciprocity in Greek religion." Reciprocity in ancient Greece. Eds. C. Gill, N. Postlethwaite, and R. Seaford. Oxford: Clarendon Press. 105-25.

---. 1996. Athenian religion: A history. Oxford: Clarendon Press.

Price, Simon. 1999. Religions of the ancient Greeks. Cambridge: Cambridge UP. van Baal J. 1973. "Offering, sacrifice and gift." Numen 23: 161-178.

van Straten, F. T. 1981. "Gift for the gods." Faith, hope and worship. Ed H. S. Versnel. Leiden: Brill, 65151.

Vlastos, Gregory. 1991. "Socratic piety." In Socrates: Ironist and philosopher. 1991. Cambridge, Cambridge UP. 157-178.

Yunis, H. 1988. A new creed: Fundamental religious belief in the Athenian polis and Euripidean drama. Gottingen: Vanderhoeck and Ruprecht.

Zaidman, L. B. and Pantel, P. S. 1992. Religion in the Ancient Greek City. Trans. by Paul Cartledge. Cambridge: Cambridge UP. 